\title{
PENGARUH STANDAR KEAMANAN PANGAN TERHADAP EKSPOR PRODUK BIOFARMAKA INDONESIA
}

\author{
Purwono Nugroho ${ }^{1}$, Muhammad Firdaus ${ }^{2}$, Alla Asmara ${ }^{2}$ \\ ${ }^{1}$ Mahasiswa Magister Ilmu Ekonomi, FEM IPB \\ ${ }^{2}$ Staf Pengajar FEM IPB
}

\begin{abstract}
There have been growing concerns about the effects of food safety standards on agricultural trade throughout the world. One of the food safety standards applied in international trade is the adoption of maximum residue limits of pesticides. This research uses panel gravity model to analyze the effect of maximum residual limit (MRL) of pesticides imposed by importing countries on export of Indonesia's medicinal plant products. The results show that stringent food safety standards imposed by importing countries have a negative and statistically significant effect on Indonesia's export of medicinal plant products. The results also show that volume of Indonesia's medicinal plant products exports are influenced by real GDP of exporter and importer, population, production, economic distance, and ad valorem tariff.
\end{abstract}

Keywords: food safety standard, Gravity model, Panel data, Medicinal plant products.

\section{PENDAHULUAN}

Dengan adanya peningkatan liberalisasi pasar agroindustri dan rantai suplai makanan seluruh dunia, jaminan kualitas dan keamanan pangan telah menjadi perhatian utama. Perdagangan global membutuhkan produk berstandar. Perlindungan konsumen telah menjadi prioritas dalam pembuatan kebijakan di pasar konsumen besar Amerika Serikat dan Uni Eropa.

Ada standar keamanan pangan di negara-negara maju, seperti pengetatan residu pestisida di Amerika Serikat selama dekade terakhir. Banyak peraturan baru melibatkan persyaratan untuk kontrol proses seperti sistem Hazard Analysis Critical Control Point (HACCP) yang merupakan pendekatan untuk pencegahan, pemantauan, dan pengendalian bahaya yang dapat diterapkan untuk setiap proses produksi.

Regulasi baru didasarkan pada penilaian risiko secara ilmiah dan karena bahaya bisa masuk ke pasokan makanan di salah satu dari beberapa titik, pengawasan keamanan pangan dilakukan mulai dari lahan pertanian sampai dengan meja makan (Will dan Guenter, 2007).

Peraturan baru di negara-negara maju pasti memiliki implikasi bagi produsen pangan di negara berkembang, termasuk Indonesia. Eksportir dari negara berkembang sering menghadapi kesulitan dalam memenuhi peraturan keselamatan pangan yang semakin ketat yang dikenakan oleh negara-negara maju. Bantuan teknis, investasi oleh produsen, dan kebijakan baru di negara berkembang memainkan peran dalam membantu eksportir negara berkembang mempertahankan akses pasarnya.

Indonesia merupakan negara berkembang beriklim tropis yang mempunyai keanekaragaman hayati yang melimpah. Hal ini membuat Indonesia yang mempunyai lahan pertanian seluas 100,7 juta Ha dapat ditanami berbagai jenis tanaman yang mempunyai nilai ekonomis dan dapat 
diperdagangkan baik di pasar domestik maupun pasar internasional. Kementerian Pertanian membagi tanaman pertanian menjadi tiga bagian yaitu tanaman perkebunan, tanaman pangan dan hortikultura.

Hortikultura terdiri atas empat kelompok yaitu kelompok buah-buahan, sayuran, tanaman obat (biofarmaka), dan tanaman hias. Keempat kelompok ini mempunyai potensi yang besar untuk dikembangkan sebagai usaha agribisnis yang akan mendorong peningkatan pendapatan petani khususnya petani hortikultura.

Produk hortikultura merupakan produk yang potensial karena bernilai ekonomis tinggi dan mempunyai permintaan pasar yang tinggi. Permintaan terhadap tanaman obat dalam beberapa tahun terakhir meningkat seiring dengan perubahan pola hidup masyarakat modern yaitu kembali ke alam (back to nature). Tanaman biofarmaka digunakan sebagai alternatif pengobatan disamping obatobatan kimia yaitu sebagai obat herbal.

$$
\text { Sisi penawaran produk }
$$

biofarmaka Indonesia dapat dilihat dari volume produksi. Semakin tinggi volume produksi maka potensi ekspornya juga semakin besar. Berdasarkan data BPS (2016), dalam kurun waktu 2003 sampai dengan 2013, data produksi komoditi biofarmaka untuk komoditas temulawak menunjukkan trend kenaikan yang tipis, sedangkan pada tahun 2014, produksi temulawak mengalami kenaikan tajam dari tahun sebelumnya.

Produksi Jahe mengalami trend yang bervariasi periode tahun, pada tahun 2007 sampai dengan 2011 mengalami pe-nurunan produksi, sedangkan pada tahun 2011 sampai dengan 2014 mengalami kenaikan produksi dengan kenaikan tajam pada tahun 2014.

Sejak berdirinya World Trade Organization (WTO) pada tahun 1995, melalui perjanjian multilateral, plurilateral dan bilateral, negara-negara anggotanya bersepakat untuk menurunkan tarif untuk produk pertanian secara bertahap. Walaupun terjadi penurunan tarif produk pertanian, hambatan perdagangan di sektor pertanian tidak berkurang.

Banyak negara menggunakan instrumen hambatan perdagangan non tarif untuk melindungi industri dalam negeri dari ancaman produk impor. Dalam situasi seperti ini, hambatan perdagangan non tarif menggantikan kebijakan tarif sebagai salah satu hambatan utama dalam perdagangan produk pertanian (Song, et al. 2010).

Hambatan perdagangan non tarif salah satunya merupakan penerapan standar keamanan pangan berupa penetapan batas ambang maksimal untuk residu pestisida yang semakin ketat oleh negara pengimpor. Hal itu menjadi tantangan sekaligus hambatan bagi negara eksportir (Song, et al. 2010).

Pada umumnya, negara-negara berpenghasilan tinggi umumnya dikenal memiliki standar keamanan pangan yang ketat, terutama standar Sanitary and Phitosanitary (SPS) yang lebih tinggi. Standar SPS ini merupakan aturan yang diterapkan untuk melindungi kesehatan manusia, hewan atau tanaman dari resiko penyebaran hama dan penyakit serta resiko dari bahan tambahan pangan, racun dan terkontaminasinya makanan. Semakin tinggi GDP per kapita suatu negara, maka rata-rata jumlah standar per produk akan semakin meningkat (Ferro et al, 2015). 
Tabel 1 Jumlah Penolakan Ekspor Produk Pangan Indonesia

\begin{tabular}{lcccccc}
\hline \multirow{2}{*}{ Negara Pengimpor } & \multicolumn{7}{c}{ Tahun } \\
\cline { 2 - 7 } & 2006 & 2007 & 2008 & 2009 & 2010 & Total \\
\hline Australia & 73 & 52 & 40 & 48 & 38 & 251 \\
Uni Eropa & 43 & 23 & 14 & 16 & 23 & 119 \\
Jepang & 24 & 59 & 26 & 35 & 44 & 188 \\
Amerika Serikat & 327 & 383 & 327 & 264 & 313 & 1614 \\
Total & 467 & 517 & 407 & 363 & 418 & 2712 \\
\hline
\end{tabular}

Selain itu, berdasarkan data, antara tahun 2009 sampai dengan 2013, negara-negara maju seperti Amerika Serikat, Jepang, Korea Selatan dan Taiwan cenderung melakukan notifikasi SPS dengan jumlah lebih banyak dibandingkan negara berkembang seperti Indonesia, Vietnam dan India. Dalam perdagangan produk pertanian di pasar global, ekspor produk pertanian Indonesia banyak mengalami penolakan di pasar dunia.

Berdasarkan data pada Tabel 1, antara tahun 2006 sampai dengan 2010 terdapat 2712 penolakan ekspor pangan Indonesia di empat negara pengimpor yaitu Australia, Uni Eropa, Jepang dan Amerika Serikat. Angka penolakan ratarata per tahun ekspor pangan Indonesia tertinggi yaitu di pasar Amerika Serikat yaitu 323 penolakan per tahun, diikuti penolakan di pasar Australia yaitu 50 penolakan per tahun, pasar Jepang 38 penolakan per tahun dan di pasar Uni Eropa 24 penolakan per tahun. Berdasarkan data UNIDO (2010), ekspor produk pertanian ke Uni Eropa antara tahun 2002-2008 yang mengalami penolakan senilai US \$ 548 juta sedangkan nilai ekspor produk pertanian Indonesia yang mengalami penolakan di Amerika Serikat bernilai US \$ 458 juta.

Ekspor produk jahe ke negara tujuan ekspor dapat dilihat pada Gambar 2. Ekspor produk jahe Indonesia ke 8 (delapan) negara tujuan ekspor secara umum mengalami pertumbuhan yang fluktuatif di tiap Negara tujuan ekspor. Negara pengimpor produk jahe Indonesia terbesar yaitu Jepang, Belanda, Malaysia, Singapura dan Amerika Serikat. Empat negara pengimpor lain yaitu Australia, Arab Saudi dan Filipina mengimpor dalam jumlah yang relatif lebih kecil.

Penerapan batas maksimum pestisida di negara tujuan ekspor berpengaruh dalam menurunkan nilai ekspor produk jahe Indonesia. Pada Gambar 2, penurunan nilai ekspor jahe ke Amerika Serikat terjadi pada tahun 2011, di sisi lain Amerika Serikat mulai memberlakukan batas maksimum pestisida Alpha Cypermethrin untuk produk Jahe pada tahun 2010. Demikian halnya dengan nilai ekspor jahe ke Malaysia juga mengalami penurunan pada tahun 2005 bersamaan dengan penerapan batas maksimum pestisida Alpha Cypermethrin pada tahun yang sama.

Ekspor produk temulawak ke negara tujuan ekspor dapat dilihat pada Gambar 2. Ekspor produk temulawak Indonesia ke 10 (sepuluh) negara tujuan ekspor secara umum mengalami pertumbuhan yang fluktuatif di tiap negara tujuan ekspor. Negara pengimpor produk temulawak Indonesia terbesar yaitu Jepang, Singapura, Amerika Serikat, India dan Belanda. 


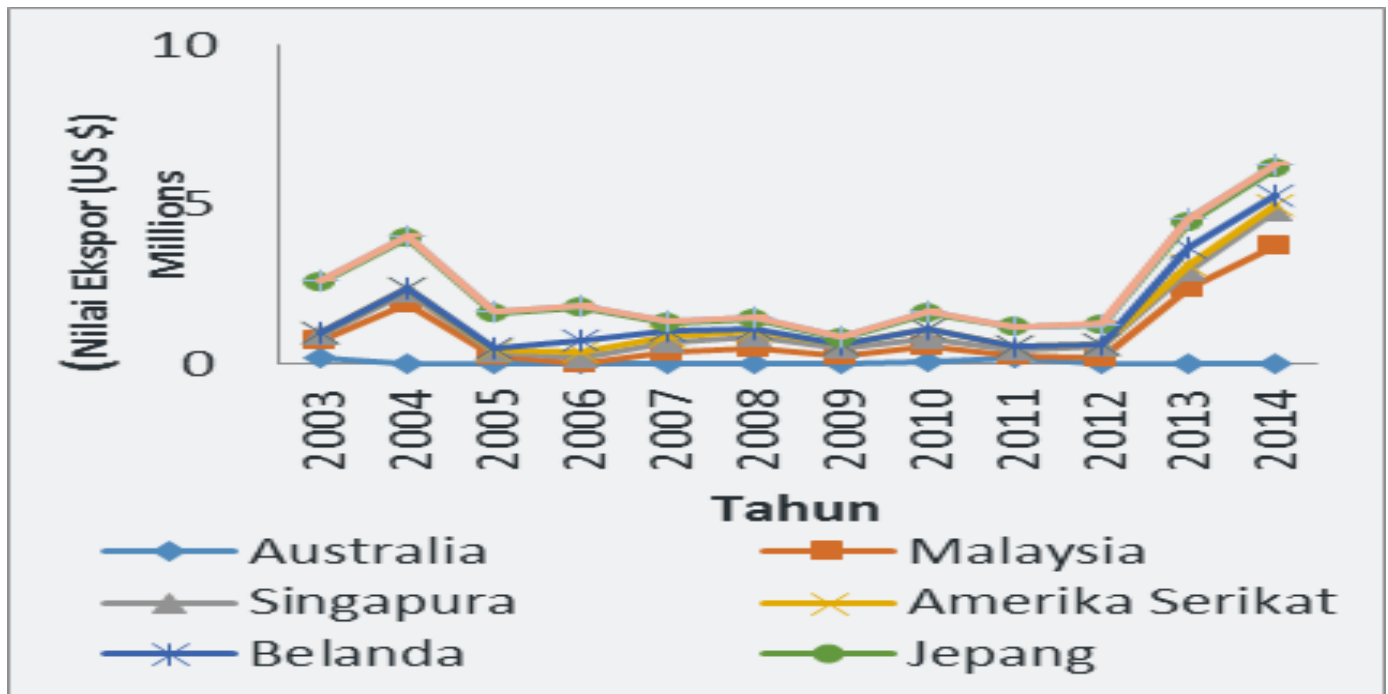

Gambar 1 Nilai Ekspor Jahe Indonesia ke tujuan ekspor

Lima negara pengimpor lain yaitu Hongkong, Taiwan, Malaysia, Vietnam dan Arab Saudi mengimpor dalam jumlah yang relatif lebih kecil. Penerapan batas maksimum pestisida di negara tujuan ekspor berpengaruh dalam menurunkan nilai ekspor produk temula-wak Indonesia.

Berdasarkan grafik pada Gambar 3 , penurunan nilai ekspor temulawak ke Malaysia terjadi pada tahun 2011, di sisi lain Malaysia mulai memberlakukan batas maksimum pestisida Bifenthrin untuk produk temulawak pada tahun 2011. Demikian halnya dengan nilai ekspor temulawak ke Singapura juga mengalami penurunan pada tahun 2011 bersamaan dengan penerapan batas maksimum pestisida Bifenthrin pada tahun yang sama.

Perkembangan ekspor perlu diberi perhatian khusus karena Indonesia sebagai negara yang mempunyai keanekaragaman hayati yang berlimpah dan lahan pertanian yang luas seharusnya memproduksi dan mengeskpor produk pertanian khususnya produk biofarmaka sehingga dapat mensejahterakan petani dan rakyat Indonesia. Ada beberapa faktor yang menyebabkan kenaikan maupun penurunan ekspor produk biofarmaka yaitu faktor daya saing produk ekspor biofarmaka, tingkat produksi serta adanya hambatan perdagangan. Walaupun ada banyak faktor yang mempengaruhi kinerja ekspor produk biofarmaka, standar keamanan pangan yang semakin ketat diterapkan di negara importir diindikasikan sebagai salah satu hambatan utama dalam perdagangan produk hortikultura sekarang ini setelah era hambatan tarif mulai berakhir. 


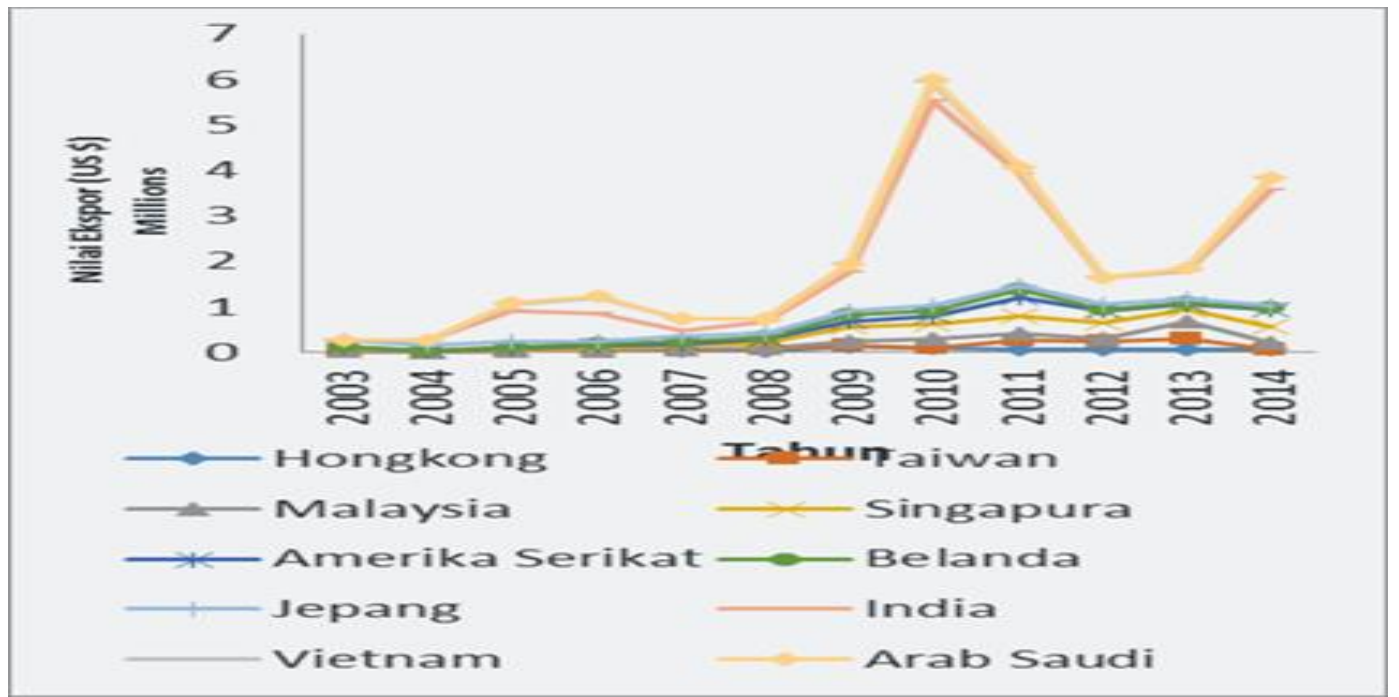

Gambar 2 Nilai Ekspor Temulawak Indonesia ke tujuan ekspor

Ruang lingkup produk yang dianalisis yaitu jahe dan temulawak. Periode analisis yang digunakan yaitu 2003 sampai dengan 2014. Negara tujuan ekspor berbeda-beda untuk jahe dan temulawak bergantung kontinuitas dan besarnya ekspor produk.

Hipotesis paper ini yaitu bahwa Gross Domestic Product (GDP) riil Indonesia, GDP riil negara tujuan ekspor, populasi, dan produksi mempunyai pengaruh positif terhadap volume ekspor biofarmaka Indonesia. Variabel jarak ekonomi, tarif impor dan pengetatan batas maksimum residu pestisida mempunyai pengaruh negatif terhadap volume ekspor biofarmaka Indonesia.

\section{TINJAUAN PUSTAKA}

\section{Hambatan Tarif}

Tarif merupakan suatu kebijakan perdagangan yang paling umum yaitu pajak yang dikenakan atas barangbarang yang diimpor. Selain itu, tarif merupakan bentuk kebijakan perdagangan yang paling tua dan secara tradisional telah digunakan sebagai sumber penerimaan pemerintah (Krugman \& Obsfeld, 2003). Tarif adalah hambatan perdagangan yang berupa penetapan pajak atas barangbarang impor atau barang-barang dagangan yang melintasi daerah pabean (custom area). Apabila suatu barang impor dikenakan tarif, maka harga jual barang tersebut di negara pengimpor menjadi lebih tinggi sehingga menyebabkan masyarakat enggan untuk membeli barang tersebut, sehingga barang-barang hasil produksi dalam negeri lebih banyak dibeli oleh masyarakat.

Menurut Krugman dan Obstfeld (2003) mekanisme perhitungan tarif, dibagi:

> Ad valorem duties, yakni biaya pabean yang tingginya dinyatakan dalam presentasi dari nilai barang yang dikenakan bea tersebut.

> Specific duties, yakni biaya pabean yang tingginya dinyatakan untuk setiap ukuran fisik dari barang yang dikenakan bea tersebut.

Compound duties, yakni biaya pabean yang tingginya adalah hasil kombinasi dari ad valorem dan specific duties.

\section{Hambatan Non Tarif}

Pemerintah membuat peraturan administratif yang bersifat teknis yang berhubungan dengan standar produk, 
keamanan pangan, kesehatan, standar lingkungan, keselamatan listrik yang dapat menghambat masuknya produk impor. Non Tariff Measures (NTMs) mencakup semua kebijakan yang berhubungan dengan biaya perdagangan yang dikeluarkan mulai dari produksi sampai dengan konsumen akhir, kecuali kebijakan tarif.

Klasifikasi NTMs oleh UNCTAD adalah taksonomi semua aturan-aturan yang dianggap relevan dalam situasi saat ini dalam perdagangan internasional. Klasifikasi tersebut adalah proses berkembang yang harus beradaptasi dengan realitas perdagangan dan kebutuhan pengumpulan data internasional.

Klasifikasi ini terdiri atas aturanaturan teknis dan non-teknis, seperti aturan Sanitary and Phitosanitary (SPS), Technical Barrier to Trade (TBT) dan aturan tradisional lainnya digunakan sebagai instrumen kebijakan komersial, misalnya kuota, pengendalian harga, pembatasan ekspor, atau tindakan perlindungan perdagangan kontingen, serta aturan-aturan di kawasan pabean, seperti kompetisi, aturan investasi yang terkait dengan perdagangan, pengadaan pemerintah atau pembatasan distribusi.

Klasifikasi aturan-aturan non-tarif meliputi 16 bab (A ke P), dan setiap bab dibagi menjadi kelompok dengan kedalaman hingga tiga tingkat. Bab A berhubungan dengan Sanitary and Phytosanitary, yang umumnya disebut sebagai SPS. Bab ini mengumpulkan aturan-aturan seperti pembatasan untuk bahan pangan dan memastikan keamanan pangan, dan hal tersebut untuk mencegah penyebaran penyakit atau hama. Bab A juga mencakup semua aturan-aturan penilaian kesesuaian yang berhubungan dengan keamanan pangan, seperti sertifikasi, pengujian dan inspeksi, dan karantina.
Definisi SPS measures yaitu aturan yang diterapkan untuk melindungi kehidupan manusia dan dan hewan dari risiko akibat bahan tambahan pangan, kontaminan, racun atau organisme penyebab penyakit dalam pangan yang dikonsumsi; untuk melindungi manusia dari tanaman atau hewan pembawa penyakit; untuk melindungi hewan atau tanaman dari hama, penyakit atau organisme penyebab penyakit; untuk mencegah atau membatasi kerusakan ke sebuah negara dari masuk dan berkembang atau penyebaran hama; dan untuk melindungi keanekaragaman hayati. Aturan ini juga melindungi kesehatan ikan dan hewan liar dan juga hutan dan tanaman liar.

Secara lebih rinci, Sanitary and Phitosanitary dibagi menjadi aturan teknis dan prosedur penilaian kesesuaian. Aturan teknis mencakup larangan impor karena alasan SPS; batas toleransi residu dan zat yang dilarang digunakan; pelabelan, penandaan dan persyaratan pengemasan; persyaratan higienis; perlakuan untuk menghilangkan hama tanaman dan hewan serta organisme penyebab penyakit pada produk akhir; persyaratan lain pada proses produksi atau pasca produksi. Prosedur penilaian kesesuaian mencakup beberapa beberapa hal yaitu persyaratan registrasi produk, persyaratan pengujian, persyaratan sertifikasi persyaratan inspeksi, persyaratan ketertelusuran dan persyaratan karantina serta persyaratan lain yang menyangkut SPS.

\section{Kebijakan Standar Keamanan Pangan}

Standar Sanitary and Phitosanitary adalah segala aturan yang diterapkan untuk melindungi manusia atau hewan atau kesehatan dari resiko akibat bahan tambahan, kontaminan, 
racun atau organisme penyebab penyakit dalam makanan, minuman atau bahan pangan. Standar ini mencakup semua aturan, persyaratan dan prosedur termasuk kriteria produk akhir; proses dan metode produksi; pengujian; inspeksi, sertifikasi dan prosedur penerimaan; perlakuan karantina termasuk persyaratan yang berhubungan dengan transportasi hewan atau tanaman, atau dengan bahan yang dibutuhkan berhubungan penyelamatan selama pemindahan; provisi pada metode statistik, prosedur pengambilan contoh dan metode pengujian resiko; dan pengemasan serta persyaratan pelabelan secara langsung terkait keamanan pangan (Osiemo, 2012).

$$
\text { Perjanjian tentang SPS }
$$

mengamanatkan hak dan kewajiban negara anggota WTO terkait perlindungan kesehatan manusia, hewan dan tanaman. Aturan SPS didefinisikan sebagai aturan bagi negara anggota WTO diterapkan untuk:

1. Melindungi kesehatan atau hidup hewan dan tanaman dari resiko yang berasal dari masuknya, pembentukan atau penyebaran hama, penyakit, organisme pembawa penyakit atau organisme penyebab penyakit;

2. Melindungi hidup atau kesehatan manusia atau hewan dari resiko yang berasal dari bahan tambahan, kontaminan, racun, atau organisme penyebab penyakit pada makanan, minuman atau bahan pangan lainnya;

3. Melindungi kesehatan atau hidup manusia dari resiko yang berasal dari tanaman atau hewan pembawa penyakit, dan dari hama hewan atau tanaman, penyakit, organisme penyebab penyakit, atau dari masuknya, perkembangbiakan atau penyebaran hama;
4. Mencegah atau membatasi kerusakan karena masuknya, perkembangbiakan atau penyebaran hama.

Perjanjian SPS ini mempunyai beberapa prinsip antara lain:

1. Nondiskriminasi adalah tindakan yang sama diterapkan pada importir serta produsen dalam negeri. Semua mitra dagang tunduk pada persyaratan yang sama.

2. Transparansi adalah informasi tentang ketentuan SPS mudah diakses. Ada prosedur yang ditetapkan untuk pemberitahuan dalam kasus tindakan baru atau ada perubahan.

3. Proporsional adalah intervensi yang sebanding dengan risiko kesehatan yang akan dikendalikan.

4. Kesetaraan adalah adanya saling pengakuan antara mitra dari tindakan yang berbeda untuk mencapai tingkat perlindungan yang sama.

5. Penggunaan tindakan berbasis ilmu pengetahuan: langkah-langkah untuk melindungi tanaman, hewan, dan kesehatan manusia didasarkan pada prinsip-prinsip ilmiah dengan bukti ilmiah yang cukup. Umumnya, hal inimembutuhkan penilaian resiko dan definisi tingkat resiko yang dapat diterima

6. Regionalisasi. Prinsip ini mengakui kemungkinan penyakit atau negarahamayang terkena memiliki area penyakit atau bebas hama atau wilayah dan memungkinkan ekspor dari penyakit tersebut atau daerah bebas hama atau wilayah.

Penelitian - penelitian yang berhubungan dengan standar keamanan pangan menyebutkan bahwa yang dimaksud dengan kebijakan standar keamanan pangan yaitu penerapan batas ambang maksimum residu pestisida atau racun tertentu. Maximum Residual Limit 
(MRL) adalah indeks yang mewakili konsentrasi maksimum residu pestisida (dinyatakan sebagai $\mathrm{mg} / \mathrm{kg}$ ) secara hokum diizinkan dalam komoditas pangan dan pakan ternak.

Batas maksimum residu pada impor pangan ditetapkan oleh masingmasing negara dan yang diterapkan sebagai standar peraturan di perbatasan/kawasan pabean. Penelitian Otsuki et al. (2004) menggunakan Chlorpyrifos MRL pada buah pisang. Penelitian Chen et al. (2008) menggunakan Chlorpyrifos MRL pada sayuran dan Oxytetracycline MRL pada produk perikanan. Penelitian Wei et al (2012) menggunakan Endosulfan, Fenvalerate, Flucythrinate MRL pada produk teh. Penelitian Wei et al. (2012) yang lain juga menggunakan Chloromycetin MRL pada produk madu. Penelitian Nugroho menggunakan batas ambang maksimum pada Ochratoxin A yang diterapkan di Uni Eropa dan Carbaryl yang diterapkan di Jepang untuk produk kopi.

\section{Penelitian Terdahulu}

Penelitian tentang dampak hambatan perdagangan non tarif telah banyak dilakukan, akan tetapi di Indonesia sendiri penelitian mengenai dampak penerapan standar keamanan pangan terhadap ekspor produk hortikultura masih sangat terbatas. Penelitian mengenai hal ini banyak menggunakan Gravity Model. Otsuki et al. (2001) meneliti dampak harmonisasi baru terhadap standar aflatoxin yang diterapkan di Uni Eropa terhadap ekspor pangan dari Afrika. Analisis menggunakan gravity model untuk mengestimasi dampak perubahan dalam tingkat perbedaan proteksi dalam standar Uni Eropa yang dibandingkan dengan standar internasional. Penelitian ini meng-gunakan data survei perdagangan da peraturan dari lima belas negara Eropa dan sembilan negara Afrika antara tahun 1989 sampai dengan 1998. Hasil penelitian yaitu implementasi standar aflatoxin yang baru di Uni Eropa mempunyai dampak negatif terhadap ekspor produk sereal, buah kering dan kacang dari Afrika. Standar baru ini akan menyelamatkan 1,4 nyawa per milyar orang dan akan menurunkan ekspor sebanyak 64\% atau senilai US \$ 670 juta.

Penelitian Nugroho (2014) meneliti pengaruh regulasi yang spesifik terhadap perdagangan kopi Indonesia dibandingkan dengan peraturan umum dunia tentang standar keamanan pangan kopi. Model yang digunakan yaitu gravity modeldengan panel data sepuluh negara importir kopi dalam periode 2002 sampai dengan 2011. Kesimpulan penelitian ini yaitu bahwa regulasi tentang OchratoxinA yang diterapkan oleh semua negara pengimpor mempunyai pengaruh signifikan terhadap perdagangan kopi Indonesia dibandingkan regulasi spesifik yang diterapkan oleh suatu negara (Jepang).

Wei et al. (2012) meneliti dampak penerapan standar keamanan pangan terhadap ekspor teh dari China. Model yang digunakan yaitu gravity modeldengan data sebanyak 31 (tiga puluh satu) negara importir teh selama periode 1996 sampai dengan 2009. Kesimpulan yang dihasilkan yaitu penerapan batas ambang maksimal pestisida oleh negara importir teh berpengaruh signifikan terhadap ekspor produk teh Cina.

Penelitian lain dari Wei et al (2012) menganalisis pengaruh penerapan standar keamanan pada madu dengan menggunakan batas ambang maksimum residu Chloromycetin yang diterapkan pada negara importir utama terhadap ekspor. Dengan menggunakan gravity model, hasil analisis menunjukkan bahwa walaupun produksi 
madu di China mengalami peningkatan yang signifikan, akan tetapi ekspor produk madu mengalami penurunan sejak tahun 2000 karena adanya standar keamanan madu yang lebih ketat di negara importir utama.

Dou et al (2013) meneliti dampak penerapan standar keamanan pangan terhadap ekspor produk sayuran dan buah-buahan dari China. Penelitian ini menganalisis pengaruh Maximum Residual Limit (MRL) dari pestisida yang diterapkan di negara importir terhadap ekspor produk sayuran dan buah-buahan China menggunakan gravity model. Hasilnya yaitu walaupun biaya transportasi dan besaran tarif masih menjadi faktor penghambat utama bagi ekspor sayuran dan buahbuahan dari China, tetapi didapatkan juga hasil bahwa ekspor produk tersebut dipengaruhi jumlah pestisida yang diatur di negara importir.

Song dan Chen (2010) melakukan analisis dampak jangka pendek dan jangka panjang penerapan peraturan standar keamanan pangan terhadap perdagangan secara umum. Analisis menggunakan data perdagangan agregat mendapatkan hasil bahwa aturan keamanan pangan mempunyai dampak negatif yang signifikan terhadap ekspor jangka pendek China, tetapi dalam jangka panjang aturan ini akan berdampak positif terhadap ekspor produk pertanian China.

\section{METODE PENELITIAN}

Data yang digunakan dalam penelitian ini adalah data runut waktu tahunan (time series) periode 2003-2014 dan cross section dari 8 negara importer jahe dan 10 negara importer temulawak. Data yang digunakan dalam paper ini adalah data sekunder yang diperoleh dari berbagai sumber (Tabel 2). Analisis pengaruh standar keamanan pangan terhadap ekspor biofarmaka Indonesia digunakan gravity model dengan data panel.

Tabel 2 Jenis dan Sumber Data

\begin{tabular}{|c|c|c|}
\hline Jenis Data & Satuan & Sumber Data \\
\hline Volume Ekspor Biofarmaka & $\mathrm{Kg}$ & BPS/FAO \\
\hline Produk Domestik Bruto & US Dollar & World Bank \\
\hline Negara importir biofarmaka (tahun dasar 2005) & & \\
\hline $\begin{array}{l}\text { Produk Domestik Bruto Indonesia (tahun dasar } \\
\text { 2005) }\end{array}$ & US Dollar & World Bank \\
\hline Jumlah penduduk negara pengimpor & Jiwa & World Bank \\
\hline Produksi tahunan biofarmaka & Ton & BPS \\
\hline $\begin{array}{l}\text { Jarak antara ibukota negara Indonesia dengan } \\
\text { ibukota negara importir biofarmaka }\end{array}$ & Kilometer & CEPII \\
\hline Tarif import (ad valorem) & Persen $(\%)$ & WTO \\
\hline Maximum Residual Limit Pestisida & ppm & $\begin{array}{l}\text { CODEX, FDA, } \\
\text { globalmrl.com }\end{array}$ \\
\hline
\end{tabular}

\section{Gravity Model}

Metode analisis yang digunakan untuk melihat pengaruh penerapan standar keamanan pangan terhadap kinerja ekspor produk biofarmaka yaitu gravity model. Model ini pertama kali dipakai oleh Tinbergen (1962) untuk menentukan pola standar perdagangan internasional. Penelitian-penelitian yang berhubungan dengan standar keamanan pangan menyebutkan bahwa yang 
dimaksud dengan kebijakan standar keamanan pangan yaitu penerapan batas ambang maksimum pestisida atau racun tertentu.

Maximum Residual Limit (MRL) adalah indeks yang mewakili konsentrasi maksimum residu pestisida (dinyatakan sebagai $\mathrm{mg} / \mathrm{kg}$ ) secara hukum diizinkan dalam komoditas pangan. Batas maksimum residu pada impor pangan ditetapkan oleh masingmasing negara dan yang diterapkan sebagai standar peraturan di perbatasan.

\section{Spesifikasi Model}

Model persamaan gravitasi yang digunakan dalam paper ini mengacu pada penelitian Wei et al (2012) dan Chen et al (2008) yaitu sebagai berikut:

$$
\begin{aligned}
{\ln \_V E_{i t}^{\mathrm{k}}=\alpha_{0}} & \alpha_{1} \ln G D P R I_{t} \\
& +\alpha_{2} \ln G D P R_{i t}+\alpha_{3} \ln P O P_{i t} \\
& +\alpha_{4} \ln P R O D_{t}^{k} \\
& +\alpha_{5} \ln D I S T_{i t}+\alpha_{6} \ln \mathrm{MRL}_{\mathrm{it}}^{\mathrm{k}} \\
& +\alpha_{7} \ln T R F_{i t}^{k}+\alpha_{8} D_{i t}+\varepsilon_{i t}
\end{aligned}
$$

Dimana $V_{\mathrm{it}}^{\mathrm{k}}$ untuk volume ekspor biofarmaka Indonesia dengan $\mathrm{k}$ komoditas jahe atau temulawak ke negara tujuan $\mathrm{i}$ pada tahun $\mathrm{t}(\mathrm{kg})$, GDPRI $_{t}$ untuk produk domestik bruto riil Indonesia pada tahun $\mathrm{t}$ (US \$), GDPR $_{\text {it }}$ untuk produk domestik bruto negara tujuan ekspor (i) pada tahun $\mathrm{t}$ (US \$), POP it untuk jumlah penduduk negara tujuan ekspor (jiwa), $P R O D_{t}^{k}$ untuk jumlah produksi biofarmaka untuk komoditas jahe atau temuawak

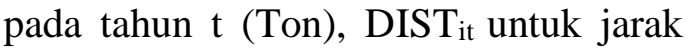
ekonomi Indonesia dengan negara tujuan ekspor, MRL $\mathrm{it}_{\mathrm{it}}^{\mathrm{k}}$ untuk batas ambang maksimal residu pestisida produk $\mathrm{k}$ di negara tujuan pada tahun $\mathrm{t}$, $T R F_{i t}^{k}$ untuk tarifimpor (ad valorem) produk k di negara tujuan ekspor pada tahun $\mathrm{t}, \mathrm{D}_{\text {it }}$ merupakan variabeldummy yang bernilai 1 jika MRL pestisida telah diberlakukan, dan bernilai 0 jika sebaliknya, $\varepsilon_{i t}$ merupakan error term.

\section{HASIL DAN PEMBAHASAN}

Paper ini mengaplikasikan gravity model untuk menganalisis pengaruh standar keamanan pangan (MRL Pestisida) terhadap ekspor biofarmaka Indonesia. Volume/jumlah ekspor tiap komoditi biofarmaka diregresikan dengan GDP rill negara tujuan ekspor tiap komoditi, jumlah penduduk negara tujuan ekspor, jarak ekonomi antara Indonesia dengan negara tujuan ekspor, jumlah produksi, tariff import ad valorem dan batas maksimum residu pestisida tertentu.

Analisis menggunakan data panel dengan teknis estimasi Common Effect (Pooled Least Square/PLS) yang diboboti dengan SUR. Teknik estimasi ini dipilih karena menghasilkan koefisien variabel bebas yang signifikan dan sesuai dengan hipotesis serta menghasilkan nilai koefisien determinasi $\left(\mathrm{R}^{2}\right)$ tinggi. Pembobotan SUR adalah salah satu jenis pembobotan yang dapat mengatasi masalah heteroskedastisitas dan autokorelasi antara individu dalam data panel. 
Tabel 3 Hasil Estimasi Variabel Penduga Volume Ekspor Biofarmaka Indonesia

\begin{tabular}{|c|c|c|}
\hline Variabel & Jahe & Temulawak \\
\hline Ln(GDPRI) & $-0,500$ & $6,455 * * *$ \\
\hline $\operatorname{Ln}(G D P R)$ & $2,858 * * *$ & $0,347 * *$ \\
\hline $\mathrm{Ln}(\mathrm{POP})$ & $0,505 * * *$ & $0,649 * * *$ \\
\hline Ln(PROD) & $1,441 * * *$ & $-0,073$ \\
\hline Ln(DIST) & $-2,301 * * *$ & $-0,343 * * *$ \\
\hline $\operatorname{Ln}(\mathrm{TRF})$ & $-0,517 * * *$ & 0,033 \\
\hline Ln (MRL) & $1,571 * * *$ & $0,117 * * *$ \\
\hline Dummy & $-1,016^{* * *}$ & $-1,140 * * *$ \\
\hline $\mathrm{C}$ & $-63,768 * * *$ & $-179,25 * * *$ \\
\hline $\mathrm{R}^{2}$ & 0,874 & 0,907 \\
\hline Prob F-stat & 0,0000 & 0,0000 \\
\hline
\end{tabular}

Keterangan $: * * *)$ signifikan pada taraf nyata 1 persen, ${ }^{* *}$ ) signifikan pada taraf nyata 5 persen

Hasil estimasi menggunakan software Eviews 8 disajikan pada Tabel 3. Estimasi tidak dapat menggunakan Fixed Effect dan Random Effect karena variable tarif impor dan batas maksimum residu pestisida mempunyai data yang berbeda antar individu tetapi tidak berbeda antar waktu (time invariant).

Berdasarkan hasil estimasi variabel penduga volume ekspor biofarmaka Indonesia pada Tabel 3, seluruh factor yang dimasukkan pada model penduga berpengaruh terhadap volume ekspor biofarmaka Indonesia, kecuali GDP Indonesia (GPRI) pada komoditi Jahe, dan variable tariff pada ekspor temulawak.

\section{GDP Riil Indonesia}

GDP riil negara pengekspor dan negara tujuan ekspor dalam gravity model bertindak sebagai massa dua negara yang melakukan perdagangan. Berdasarkan hasil estimasi pada Tabel 5, GDP riil negara pengekspor (Indonesia) berpengaruh positif dan signifikan terhadap volume ekspor produk temulawak. Nilai koefisien GDP riil Indonesia 6.455. Hal ini berarti jika GDP rill negara pengekspor meningkat sebesar $1 \%$, maka volume ekspor produk temulawak akan meningkat sebesar $6,455 \%$, ceteris paribus. Nilai koefisien GDP riil produk jahe bernilai negatif akan tetapi tidak signifikan secara statistik.

\section{GDP Riil Negara Tujuan Ekspor}

GDP riil negara tujuan ekspor (negara pengimpor) mempunyai pengaruh positif dan signifikan terhadap volume ekspor produk jahe dan temulawak. Nilai koefisiennya menghasilkan tanda positif. Jika terjadi peningkatan GDP riil negara tujuan ekspor sebesar $1 \%$ maka pengaruhnya akan meningkatkan volume ekspor produk jahe dan temulawak Indonesia masing-masing sebesar $2,858 \%$ dan $0,347 \%$, ceteris paribus. Peningkatan pendapatan yang terjadi pada negara tujuan ekspor (negara pengimpor) akan meningkatkan permintaan ekspor produk biofarmaka Indonesia. Hasil paper ini sejalan dengan temuan yang 
dilakukan oleh Wilson dan Otsuki (2004), Chen et al (2008), Wei et al (2012), Dou et al (2013) dan Nugroho (2014).

\section{Populasi Negara Pengimpor}

Populasi negara tujuan ekspor (negara pengimpor) berpengaruh positif dan signifikan terhadap volume ekspor jahe dan temulawak. Nilai koefisiennya berturut-turut yaitu 0,505 dan 0,649. Jika terjadi peningkatan populasi negara tujuan ekspor sebesar 1\% maka pengaruhnya akan meningkatkan volume ekspor jahe dan temulawakmasing-masing sebesar $0,505 \%$ dan $0,649 \%$, ceteris paribus. Kondisi ini sesuai dengan hipotesis paper yang menjelaskan bahwa populasi negara pengimpor berpengaruh positif pada ekspor produk biofarmaka Indonesia.

Hasil paper ini sejalan dengan temuan yang dilakukan oleh Wilson dan Otsuki (2004), Chen et al (2008), Wei et al (2012), Dou et al (2013) dan Nugroho (2014). Populasi yang bertambah berbanding lurus dengan pertambahan konsumsi suatu produk pada suatu negara. Apabila produksi dalam negeri negara importir tidak mampu memenuhi kebutuhan konsumsi yang meningkat maka negara importir cenderung melakukan impor. Konsumsi yang meningkat di negara pengimpor akan meningkatkan jumlah produk biofarmaka yang diimpor. Besarnya populasi pada suatu negara menunjukkan potensi pasar yang besar bagi negara pengekspor. Populasi menjadi suatu indikasi untuk meningkatkan jumlah ekspor, sehingga dapat berpengaruh positif. Hal ini sejalan dengan paper yang dilakukan oleh Zarzoso (2004) yang menyatakan bahwa koefisien positif pada variabel populasi negara pengimpor menunjukkan ukuran suatu negara berhubungan langsung dengan perdagangan.

\section{Produksi Biofarmaka}

Variabel produksi komoditi biofarmaka merupakan proksi dari sisi penawaran produk biofarmaka Indonesia. Peningkatan produksi biofarmaka berhubungan dengan peningkatan kuantitas/volume produk yang diekspor. Hasil estimasi yang diperoleh menunjukkan bahwa variabel produksi komoditi jahe mempunyai koefisien sesuai dengan hipotesis dan signifikan secara statistik.

Koefisien produksi jahe yaitu sebesar 1,441. Jika terjadi peningkatan produksi jahe sebesar $1 \%$ maka pengaruhnya akan meningkatkan volume ekspor jahe sebesar 1,441\%, ceteris paribus. Hasil estimasi produk temulawak menghasilkan koefisien yang negatif tetapi tidak signifikan. Konsumsi biofarmaka yang meningkat di dalam negeri perlu diimbangi dengan peningkatan produksi yang signifikan sehingga Indonesia tidak bergantung pada impor biofarmaka dari negara lain.

\section{Jarak Ekonomi (Distance)}

Biaya ekspor (biaya transportasi) dalam paper ini diukur dengan nilai jarak ekonomi suatu negara. Jarak ekonomi merupakan salah satu syarat yang cukup penting pada gravity model dan besarnya jarak ekonomi akan mempengaruhi arus perdagangan ekspor secara negatif. Hasil estimasi yang diperoleh model menunjukkan bahwa variabel jarak ekonomi (economic distance) memiliki pengaruhnegatif dan signifikan terhadap volume ekspor produk jahe dan temulawak.

Nilai koefisiennya masing-masing yaitu -2,301, dan -0,343. Jika jarak 
antara negara tujuan ekspor dengan Indonesia lebih jauh 1\% maka akan menurunkan volume ekspor jahe dan temulawak masing-masing sebesar $2,301 \%$, dan 0,343\%, ceteris paribus. Nilai Koefisien estimasi pada semua produk bernilai negatif dan signifikan sehingga sesuai dengan teori ataupun hipotesis pada paper ini.

Hal ini sesuai dengan teori gravity dimana jarak mempengaruhi interaksi antara dua objek. Semakin jauh jarak negara tujuan dengan Indonesia maka semakin besar biaya transportasi untuk perdagangan yang pada akhirnya akan meningkatkan harga produk yang diperdagangkan. Hasil paper ini sejalan dengan penelitian Dou et al (2013) yang menyatakan bahwa faktor jarak masih menjadi penghambat utama pada perdagangan biofarmaka antar negara.

\section{Tarif}

Fakta menunjukkan bahwa hambatan tarif sekarang ini rendah di hampir semua negara secara rata-rata yaitu 5\% untuk negara maju dan dengan beberapa pengecualian tarif di negara berkembang antara $10 \%$ sampai dengan $20 \%$. Secara umum, estimasi kebijakan hambatan perdagangan untuk negara industri (termasuk hambatan nontarif) adalah sebesar 8\% (Anderson dan Wincoop, 2004).

Nilai koefisien tarif pada estimasi produk jahe yaitu sebesar $-0,517$ dan signifikan secara statistik. Hal ini berarti jika tarif impor produk jahe di Negara pengimpor naik sebesar $1 \%$ maka akanmenurunkan volume ekspor jahe sebesar $0,517 \%$, ceteris paribus.

Hasil estimasi produk jahe sesuai dengan hipotesis paper yaitu tarif impor suatu produk yang tinggi akan menyebabkan kenaikan harga produk sehingga menyebabkan rendahnya impor produk tersebut. Nilai koefisien pada estimasi produk temulawak tidak sesuai dengan hipotesis paper yaitu bernilai positif tetapi tidak signifikan secara statistik.

\section{Batas Maksimum Residu Pestisida}

Paper ini mempunyai tujuan utama yaitu menganalisis pengaruh penerapan batas maksimum residu (Maximum Residual Level/MRL) pestisida produk biofarmaka oleh negara tujuan ekspor terhadap volume ekspor komoditi tersebut. Tiap produk yang dianalisis mempunyai MRL pestisida yang berbeda-beda. Pemilihan pestisida pada paper ini berdasarkan penerapan pestisida yang sama untuk kelompok negara tujuan ekspor tiap komoditi. Pestisida yang dianalisis yaitu Alpha Cypermethrin (jahe) dan Bifenthrin (temulawak).

MRL pestisida yang diterapkan oleh negara tujuan ekspor (negara pengimpor) berpengaruh positif dan signifikan terhadap volume ekspor jahe dan temulawak. Nilai koefisien MRL pestisida produk jahe dan temulawak berturut-turut yaitu 1,571 dan 0,117. Hasil itu berarti jika MRL pestisida yang diterapkan mengalami kenaikan batas maksimum residu pestisida dengan kata lainadanya pelonggaran MRL sebesar $1 \%$, maka volume ekspor jahe dan temulawak akan naik sebesar $1,571 \%$ dan $0,117 \%$.

Tanda positif dan signifikan secara statistik mendukung hipotesis paper bahwa standar keamanan pangan merupakan faktor penting yang mempengaruhi ekspor produk biofarmaka Indonesia. Selain itu, MRL pestisida dapat berpengaruh terhadap adanya diversi perdagangan, tetapi hal ini bergantung kepada kemampuan negara pengekspor untuk menyesuaikan aturan pengetatan standar (Wilson dan Otsuki, 2004). 


\section{KESIMPULAN DAN SARAN}

\section{Kesimpulan}

Berdasarkan uraian yang telah disajikan pada bahasan sebelumnya, maka dapat ditarik kesimpulan sebagai berikut:

1. Analisis data panel terhadap model gravity menunjukkan bahwa sebagian besar variabel bebas model yang dianalisis signifikan secara statistik dan memiliki koefisien sesuai dengan hipotesis. Dengan demikian, faktor-faktor yang mempengaruhi volume ekspor produk biofarmaka Indonesia yaitu GDP riil, produksi, populasi, jarak ekonomi, tariff impor dan batas maksimum residu pestisida.

2. Batas residu maksimum pestisida yang diterapkan oleh negara tujuan ekspor berpengaruh signifikan terhadap volume ekspor Indonesia produk jahe dan temulawak. Hal ini menunjukkan bahwa standar keamanan pangan yang semakin ketat di negara tujuan ekspor akan berpengaruh terhadap penurunan volume ekspor produk biofarmaka Indonesia.

\section{Saran}

Berdasarkan kesimpulan yang diperoleh, maka beberapa hal yang dapat disarankan yaitu:

1. Pemerintah perlu mendorong program peningkatan produksi biofarmaka sehingga kebutuhan pasar dalam negeri dapat dipenuhi dan menurunkan ketergantungan terhadap produk biofarmaka impor.

2. Pemerintah perlu melakukan pembenahan terkait aturan standar keamanan pangan khususnya untuk produk pertanian Indonesia sehingga kualitas produk pertanian yang dihasilkan meningkat yang pada akhirnya akan meningkatkan dayasaing dan nilai ekspornya sekaligus memperketat masuknya produk pertanian impor.

\section{DAFTAR PUSTAKA}

Anderson J. dan Wincoop E. 2004. Trade Cost. Journal of Economic Literature, Vol. 42, No.3 (Sept., 2004), pp. 691-751.

[BPS] Badan Pusat Statistik. 2014. Produksi Hortikultura. http://www.bps.go.id/site/pilihdata [ Desember 2014].

Chen C, Yang J, dan Findlay C. 2008.Measuring the Effect of Food Safety Standards on China's Agricultural Exports. Review of World Economics Vol 144 (1).

CODEX Alimentarius. 2015. Pesticide Residues in Food and Feed. http://www.codexalimentarius.net/ pestres/data/pesticides/index.html [April 2015].

Dou L, Nakagawa M, Yan F dan Li P. 2013. The Impact of Food Safety Standards on China's Export of Vegetables and Fruits. World Academy of Science, Engineering and Technology Vol : 7 2013-0529

Ferro E, Otsuki $\mathrm{T}$ and Wilson J. 2015.The effect of product standards on agricultural exports. Food Policy 50 (2015) 68-79. Published by Elsevier Ltd.

Krugman P dan Obstfeld M. 2003. International Economics Theory and Policy Sixth Edition. Boston: Addison-Wesley.

Nugroho A. 2014. The Impact of Food Safety Standard on Indonesia's Coffe Exports. Procedia Environtmental Sciences 20: 425433 
Osiemo O. 2012. Harmonization of sanitary and phytosanitary standards in international trade: the case of the EU and the COMESA. [Disertasi].

Otsuki T, Wilson J, dan Sewadeh M. 2001. Saving two in a billion: quantifying the trade effect of European food safety standards on African Exports. Food Policy 26: 495-514. Faculty of Law. University of Amsterdam

Song H, Chen K. 2010. Trade Effects and Compliance Costs of Food Safety Regulations: A Case of China. Agriculture and Agricultural Science Procedia 1: 429-438.

Tinbergen J. 1962. Shaping the World Economy: Suggestion for an International Economic Policy

Wei G, Huang J dan Yang J. 2012. The Impact of Food Safety Standard on China's Tea Export. China
Economic Review 23 (2012) 253264

Will M and Guenther D. 2007. Food Quality and Safety Standards as required by EU Law and the Private Industry.A Practitioners Reference Book. Agriculture, Fisheries and Food. Division 45.

Wilson JS dan Otsuki T. 2004. To spray or not to spray : Pesticides, banan exports, and Food Safety. Food Policy 29(2): 131-146.

[WTO] World Trade Organization. [Internet]. [Diunduh April 2015]. Tersedia:

http://tariffdata.wto.org/Default.as px?culture $=$ en-US.

Zarzoso IM. 2004. Regional Trading Agreements: New Empirical Evidence from The Gravity Model. JEL: F14, F15. Universidad Jaume I and Instituto de Economía Internacional. Castellón, Spain. 


\section{LAMPIRAN}

Lampiran 1 Hasil Eviews Komoditi Jahe

Dependent Variable: LOG(VE)

Method: Panel EGLS (Cross-section SUR)

Date: 05/28/16 Time: 14:55

Sample: 20032014

Periods included: 12

Cross-sections included: 8

Total panel (balanced) observations: 96

Linear estimation after one-step weighting matrix

\begin{tabular}{|c|c|c|c|c|}
\hline Variable & Coefficient & Std. Error & t-Statistic & Prob. \\
\hline LOG(GDPRI) & $-0,500125$ & 0,586967 & $-0,852050$ & 0,3965 \\
\hline LOG(GDPR) & 2,858400 & 0,759177 & 3,765128 & 0,0003 \\
\hline LOG(POP) & 0,505332 & 0,176424 & 2,864298 & 0,0052 \\
\hline LOG(PROD) & 1,441776 & 0,361109 & 3,992636 & 0,0001 \\
\hline LOG(DIST) & $-2,301432$ & 0,476995 & $-4,824855$ & 0,0000 \\
\hline LOG(MRLALPHACYPERMETHRIN) & 1,571157 & 0,295156 & 5,323141 & 0,0000 \\
\hline LOG(TRF) & $-0,517037$ & 0,144975 & $-3,566395$ & 0,0006 \\
\hline DBERLAKU & $-1,016449$ & 0,188516 & $-5,391837$ & 0,0000 \\
\hline C & $-63,76872$ & 21,11687 & $-3,019799$ & 0,0033 \\
\hline \multicolumn{5}{|c|}{ Weighted Statistics } \\
\hline R-squared & \multirow{5}{*}{\multicolumn{3}{|c|}{$\begin{array}{l}0,874282 \text { Mean dependent var } \\
0,862721 \text { S,D, dependent var } \\
0,988889 \text { Sum squared resid } \\
75,62786 \text { Durbin-Watson stat } \\
0,000000\end{array}$}} & 7,917756 \\
\hline Adjusted R-squared & & & & 11,08924 \\
\hline $\mathrm{S}, \mathrm{E}$, of regression & & & & 85,07744 \\
\hline F-statistic & & & & 2,003876 \\
\hline \multirow[t]{2}{*}{ Prob(F-statistic) } & & & & \\
\hline & \multicolumn{3}{|c|}{ Unweighted Statistics } & \\
\hline \multirow{2}{*}{$\begin{array}{l}\text { R-squared } \\
\text { Sum squared resid }\end{array}$} & \multirow{2}{*}{\multicolumn{3}{|c|}{$\begin{array}{l}\text { 0,549735 Mean dependent var } \\
\text { 569,4370 Durbin-Watson stat }\end{array}$}} & 10,43310 \\
\hline & & & & 1,642026 \\
\hline
\end{tabular}




\section{Lampiran 2 Hasil Eviews Komoditi Temulawak}

Dependent Variable: LOG(VE)

Method: Panel EGLS (Cross-section SUR)

Date: 05/28/16 Time: 15:43

Sample: 20032014

Periods included: 12

Cross-sections included: 10

Total panel (unbalanced) observations: 119

Linear estimation after one-step weighting matrix

\begin{tabular}{crrrr}
\hline \hline Variable & Coefficient & Std. Error & t-Statistic & Prob. \\
\hline \hline LOG(GDPRI) & 6,455984 & 0,525879 & 12,27656 & 0,0000 \\
LOG(GDPR) & 0,347312 & 0,144280 & 2,407218 & 0,0177 \\
LOG(POP) & 0,649259 & 0,069636 & 9,323556 & 0,0000 \\
LOG(PROD) & $-0,073042$ & 0,112457 & $-0,649513$ & 0,5174 \\
LOG(DIST) & $-0,343651$ & 0,062289 & $-5,516993$ & 0,0000 \\
LOG(MRLBIFENTHRIN) & 0,117255 & 0,038167 & 3,072140 & 0,0027 \\
LOG(TRF) & 0,033554 & 0,137251 & 0,244470 & 0,8073 \\
DBERLAKU & $-1,140244$ & 0,198390 & $-5,747499$ & 0,0000 \\
\multicolumn{1}{c}{ C } & $-179,2532$ & 13,68735 & $-13,09627$ & 0,0000 \\
\hline \hline & Weighted Statistics & & \\
\hline \hline R-squared & 0,907190 Mean dependent var & $-0,760240$ \\
Adjusted R-squared & 0,900440 S,D, dependent var & 28,14956 \\
S,E, of regression & 0,964032 Sum squared resid & 102,2294 \\
F-statistic & 134,4024 Durbin-Watson stat & 1,799035 \\
Prob(F-statistic) & 0,000000 & & $1,0,05386$ \\
\hline \hline & Unweighted Statistics & 1,071060 \\
\hline \hline
\end{tabular}

